\title{
Nanogram Per Milliliter Per Milligram Per Kilogram
}

National Cancer Institute

\section{Source}

National Cancer Institute. Nanogram Per Milliliter Per Milligram Per Kilogram. NCI

Thesaurus. Code C105477.

A dose calculation unit expressed in manograms per milliliter, divided by milligram per kilogram. 